\title{
Regulating Environmental Responsibility for the Multinational Oil Industry: Continuing Challenges for International Law by
}

\author{
David M. Ong*
}

\section{Abstract}

States utilise international law to create opportunities within global markets for private transnational economic actors, such as multinational oil companies, to invest and/or operate within foreign jurisdictions. However, there is a lack of directly enforceable international mechanisms against these private actors when they cause environmental damage abroad. International law responses to this problem range from the establishment of international compulsory compensation schemes, the proposed expansion of the doctrine of State responsibility to include liability for private actors and more recently, through litigation in the home States of multinational oil companies. However, both international jurisprudence and US, Dutch and British domestic case law reveal an ambivalence towards holding such private transnational economic actors legally accountable in their home State jurisdictions for violations committed abroad. Certain States (the USA and France) have responded to this ambivalence by reasserting their domestic regulatory powers to require immediate clean-up and compensation, prior to domestic judicial litigation, whereas other States (Nigeria) are unable to achieve the same level of effective enforcement due to their weaker political and economic bargaining positions.

\footnotetext{
*Professor of International \& Environmental Law, Nottingham Law School, Nottingham Trent University, UK. Email: davidm.ong@ntu.ac.uk
} 


\section{Introduction}

This essay explores the continuing legal issues arising from the non-compliance of environmental protection standards by private transnational economic actors operating beyond the national jurisdiction from which they originate. The focus here is on the activities of the multinational oil industry. This species of private transnational economic actors is taking advantage of increased opportunities to trade and especially, to invest within different national jurisdictions, following the success of world-wide efforts at trade liberalization and investment protection, established through international organizations such as the World Trade Organization (WTO), the International Centre for Settlement of Investment Disputes (ICSID), ${ }^{1}$ the Energy Charter treaty, ${ }^{2}$ as well as bilateral investment protection treaties (known as BITs). States have used international law to intervene within global markets and create opportunities for private transnational economic actors, such as multinational oil companies, to invest and/or operate within foreign jurisdictions. However, when domestic environmental protection standards are not complied with by these private actors, the lack of international mechanisms that are directly enforceable against these

\footnotetext{
${ }^{1}$ ICSID is an autonomous international institution established under the Convention on the Settlement of Investment Disputes between States and Nationals of Other States (the ICSID or the Washington Convention) with more than 140 member States. Accessible at: https://icsid.worldbank.org/ICSID/FrontServlet?requestType=CasesRH\&actionVal=ShowHome\&pag $\underline{\text { eName}=\text { AboutICSID Home }}$

2 The Energy Charter Treaty was adopted on 17 December, 1994 in Lisbon and entered into force in April 1998. As of June 2013, 47 States have ratified the Treaty and a further four States have signed but not yet ratified it. Part III of the Treaty, including Articles 10-17, covers 'Investment Promotion and Protection'. Accessible at: $\underline{\text { http://www.encharter.org/index.php?id=7\&L=0 }}$
} 
private transnational economic actors means that States have to re-intervene to regulate, or otherwise hold these actors accountable for their non-compliance of these standards. International law responses to such non-compliance range from the establishment of international compulsory compensation schemes, the proposed expansion of the doctrine of State responsibility to include liability for private actors and more recently, through litigation in the home States of these multinational oil companies. However, domestic case law from the USA, Netherlands and the UK reveals a general ambivalence towards holding such private transnational economic actors accountable in their home State jurisdictions for violations committed abroad. Jurisprudence from the International Tribunal for the Law of the Sea (ITLOS) also exhibits a reluctance to hold private actors directly accountable to public international law.

Certain States (the USA and France) have responded to this ambivalence at the international level by reasserting their domestic regulatory power to require immediate clean-up and compensation, prior to domestic judicial litigation, whereas other States (such as Nigeria) are unable to achieve the same level of effective enforcement against the multinational oil companies operating within their jurisdictions due to their weaker political and economic bargaining positions. As we will see below in the Deepwater Horizon and Erika case studies, international 'best practice' for the clean-up, remediation and compensation for oil spills were 'enforced' against the multinational oil companies involved, namely, BP, Shell and Total, even prior to any domestic judicial finding of liability. This is in stark contrast to the jurisdictional and enforcement difficulties encountered when attempting to ensure clean-up and compensation for oil pollution in the Niger Delta region, at least in part attributed to omissions by Shell (Nigeria). The relative negotiating strengths of the 
host State governments involved, namely, the US (Deepwater), France (Erika) and Nigeria (Niger Delta) clearly played a part in the different response levels by the multinational oil companies implicated in each of these case studies. This disparity is especially evident in the pro-active BP and Total responses in the US and France, respectively, as compared with the paucity of the Shell response in Nigeria.

Part I of this essay will first outline the different international and domestic legal means utilised to render these private transnational economic actors accountable, responsible and even liable, for their non-compliance of domestic environmental protection standards abroad. The international regimes established for these purposes, alongside the ambivalent results of both international case law and domestic cases from the USA, Netherlands and UK jurisdictions, will then be assessed. In Part II, the legal implications of an altogether more forceful approach taken by certain States (the USA and France) against the private transnational economic actors involved will be considered. Finally, this paper will conclude by reflecting on the viability of the different legal approaches towards rendering private transnational economic actors responsible for the environmental damage caused by their activities beyond their home State jurisdictions, in light of the forceful regulatory intervention that is still available and sometimes utilized by States.

Key to the arguments presented here is the need to recognize both the initial sense of legitimate expectation, but also more recently, the notion of social obligation that now underpins the legal relationships between private transnational economic actors and both the States they originate from and operate within. Previously, this sense of legitimate expectation manifested itself in arguments for the recognition of such private transnational economic actors as legal persons with enforceable rights against 
States, especially in the field of investment protection. More recently, the initial sense of legitimate expectation of investment protection on the part of these private economic actors has also translated into a growing sense of common obligations, accountability, and ultimately, even acceptance of responsibility on the part of these actors for their actions or omissions, where these do not accord with accepted human rights and/or environmental protection standards. However, such acceptance of corporate responsibility is usually voluntary on the part of the multinational oil company involved, rather than the result of the effective enforcement of these international norms within the domestic jurisdictions where these companies operate.

These ground-breaking legal developments are also taking place against a backdrop of unprecedented questioning of the role of the State in the political economic sphere within which these private transnational economic actors operate. In particular, the regulatory and enforcement roles of the State within their municipal and international legal frameworks are under scrutiny as never before, even in areas that were traditionally within the domain of States. While the regulatory role of the State is being questioned, alternative governance frameworks for holding private transnational economic actors legally accountable for their activities both at home and abroad have not necessarily been effective. Thus, individual States have retained their interventionist and regulatory roles over private transnational actors licensed to undertake economic activities deemed to be of significant State interest, such as the petroleum industry. In these situations, it is the relative strength of the regulatory power exerted by the host States that ultimately tips the balance either towards or against voluntary compliance by the multinational oil company involved. 


\section{International Law Responses to the Challenge of Regulating Multinational Oil Companies}

The main obstacle for public international law within this context is ensuring the effective implementation and enforcement of human rights and environmental protection standards by transnational private economic actors, especially when they operate in foreign (host State) jurisdictions, beyond their home State jurisdictions. Public international law, normally the domain of States, but increasingly also of intergovernmental organizations such as the UN, World Bank, IMF and WTO, has developed at least two ways to regulate the transnational activities of private economic actors, such as these multinational oil companies. First, via the adoption of multilayered global and regional normative instruments targeting transnational business activities. The adoption of international instruments such as the 2011 UN Guiding Principles on Business and Human Rights 3 (hereinafter, Ruggie Principles), the 2008 Organization for Economic Co-operation and Development (OECD) Guidelines for Multinational Enterprises, and the 2000 Global Compact4, are all examples of the

3 The UN Human Rights Council endorsed the 'Guiding Principles on Business and Human Rights: Implementing the United Nations 'Protect, Respect and Remedy' Framework' on 16 June 2011. These Principles were proposed by the UN Special Representative on Business and Human Rights, John Ruggie, as part of his report to the Council. Accessible from:

http://www.business-humanrights.org/UNGuidingPrinciplesPortal/Home

4 Adopted on 26 July 2000, and subject to further iterations and developments on 6 September, 2005 and 19 February, 2008, respectively, the UN Global Compact is a strategic policy and networking initiative for businesses that are committed to aligning their operations and strategies with ten universally accepted principles in the areas of human rights, labour, environment and anti-corruption. Among the ten principles that businesses commit to implementing in their activities, Principle 8 provides that they 'undertake initiatives to promote greater environmental responsibility.'

Accessible from http://www.unglobalcompact.org/ 
normative efforts of international governance institutions such as the UN and OECD in this field. These international normative exercises are designed to appeal directly to the behaviour of multinational businesses undertaking transnational activities with the aim of ensuring their compliance with, inter alia, international human rights and environmental protection standards. Notably, these international instruments confirm the application of basic human rights and environmental protection principles and standards to private transnational economic actors but do not provide any international means for enforcing these principles and standards. Indeed, the Ruggie Principles, for example, require States to provide access to effective domestic judicial and non-judicial remedies addressing business-related human rights abuses.5 However, the foundational Ruggie Principle on this issue appears to limit access to such remedies only to situations '... when such abuses occur within their territory and/or jurisdiction ...'6, thereby arguably negating the possibility of access to domestic remedies for abuses committed by businesses abroad.

The second regulatory means utilized in this context is through the institutional networks established by the above international organizations both across and within national jurisdictions aimed at rendering private economic actors that originate from those jurisdictions accountable for their risky human rights and environmental practices. These institutionalized accountability networks are beginning to make an impact on multinational oil industry activities, especially through the concerted efforts of civil society groups utilizing these networks. A recent example of both these normative and networking developments is the utilization by Amnesty International

\footnotetext{
5 See Ruggie Principles 26 \& 27, and attached commentaries, op. cit.

6 See Ruggie Principle 25 and attached commentary, ibid.
} 
and Friends of the Earth in January, 2011 of both the OECD National Contact Points (NCPs) and the OECD Committee on International Investment and Multinational Enterprises (CIME), as well as the provision of testimony before a Dutch parliamentary committee hearing, to highlight the alleged involvement of the Royal Dutch Shell oil company in the despoliation of the Niger Delta through its operations in that area.7 However, neither of these international and national governance and accountability frameworks can ultimately hold such private actors responsible and liable for any breach of international human rights and environmental standards in their transnational activities. As a recent Chatham House report on oil theft in Nigeria observes: 'In June 2013, an NCP panel in the Netherlands issued a statement criticizing Shell for publishing data that exaggerated oil theft's role as a cause of oil spills in the Niger Delta. The statement was a limited victory for environmental activists in the region, but had no discernible effect on oil theft proper.'8

The continuing difficulties faced by the alternative international governance structures established to render such private transnational economic actors accountable for their non-compliance of human rights and environmental norms abroad highlights the need for a re-configuration of international law so that it can be

\footnotetext{
7 See 'Shell accused over misleading figures on Nigeria oil spills', Amnesty International, UK Press Release on 25 January, 2011, accessible at: http://www.amnesty.org.uk/press-releases/shell-accusedover-misleading-figures-nigeria-oil-spills

8 See: Christina Katsouris and Aaron Sayne, Nigeria's Criminal Crude: International Options to Combat the Export of Stolen Oil, Royal Institute of International Affairs (Chatham House) (September, 2013) 67pp, at 63 .
} 
directly enforced against such private transnational actors in foreign jurisdictions. 9 Despite evidence of the progressive co-option of private economic actors into acceptance of international human rights and environmental protection standards by instruments such as the Ruggie Principles, OECD Guidelines and UN Global Compact, gaps remain with regard to a crucial aspect of the overall public international law system, namely, the responsibility and especially, liability of such private actors, if and when they fail in their performance of these co-opted international principles, rules and standards. The following sub-sections chart some of the possible pathways towards rendering such actors legally accountable, responsible and even liable, for their breach of international norms and standards in the human rights and environmental protection fields.

\section{A. State intervention establishing compulsory international compensation schemes}

A further international law response, within specific fields of economic activity deemed to be ultra-hazardous from an environmental perspective, is to establish international compensation schemes that extend to cover the activities of non-State, private transnational economic actors. Examples of these mechanisms are the international civil liability and compensation schemes (established by treaties) for oil

\footnotetext{
9 David M. Ong, 'International Law for Environmental Protection', in Basak Cali (ed.) International Law for International Relations, Oxford: OUP (2009) 306-329, at 321-322.
} 
spills from tanker shipping, ${ }^{10}$ and damage from nuclear power generators. ${ }^{11}$ Under these schemes, members of these industries are compelled to contribute towards compensation funds that are applicable on a world-wide basis. Focussing on the international agreements applying to oil cargo shipments, the first of these is the 1992 Civil Liability Convention (1992 CLC) which governs the liability of ship owners for oil pollution damage. Under this Convention, the registered ship owners incur strict liability for pollution damage caused by the escape or discharge of persistent oil from their ships. This means that they are liable even in the absence of fault. The compensation limits are dependent on the tonnage of the oil tanker ship, with a maximum limit of 89,770,00o Special Drawing Rights (SDRs) for ships of 140,000 gross tonnes or more. ${ }^{12}$ The International Oil Pollution Compensation Fund 1992 established under the 1992 Fund Convention, which is supplements the 1992 CLC,

\footnotetext{
${ }^{10}$ The International Oil Pollution Compensation Funds are three intergovernmental organizations (the 1971 Fund, the 1992 Fund and the Supplementary Fund) which provide compensation for oil pollution damage resulting from spills of persistent oil from tankers. Further information accessible at: http://www.iopcfunds.org/

${ }^{11}$ The international nuclear civil liability regime was initially embodied in two instruments, i.e. the Vienna Convention on Civil Liability for Nuclear Damage of 1963 and the Paris Convention on Third Party Liability in the Field of Nuclear Energy of 1960, both of these linked by a Joint Protocol adopted in 1988. The Paris Convention was later added to by the 1963 Brussels Supplementary Convention. This was followed by the adoption of a 1997 Protocol to Amend the 1963 Vienna Convention on Civil Liability for Nuclear Damage, as well as a further Convention on Supplementary Compensation for Nuclear Damage. Further information accessible at:

http://www.iaea.org/Publications/Documents/Conventions/liability.html
}

${ }^{12}$ The unit of account in the Conventions is the Special Drawing Right (SDR) as defined by the International Monetary Fund. Information accessed from http://www.iopcfunds.org/about-us/legalframework/1992-civil-liability-convention/ 
compensates victims when compensation under the 1992 CLC is unavailable or inadequate. The 1992 Fund pays compensation when:

- the damage exceeds the limit of the ship owner's liability under the 1992 CLC, or

- the ship owner is exempt from liability under the 1992 CLC, or

- the ship owner is financially incapable of meeting his obligations in full under the 1992 CLC and the insurance is insufficient to pay valid compensation claims.

The maximum compensation payable by the 1992 Fund is 203 million SDR for incidents occurring on or after 1 November 2003, irrespective of the size of the ship. For incidents occurring before that date, the maximum amount payable is 135 million SDR. These maximum amounts include the sums actually paid by the ship owner under the 1992 CLC. The 1992 Fund is financed by contributions levied on any person who has received in one calendar year more than 150,000 tonnes of crude oil and/or heavy fuel oil (contributing oil) in a Member State of the 1992 Fund.13 The Supplementary Fund Protocol, which was adopted in 2003, entered into force in 2005, thereby establishing the International Oil Pollution Compensation Supplementary Fund, 2003. The Supplementary Fund provides additional compensation beyond the amount available under the 1992 Fund Convention in 1992 Fund Member States which are also Parties to the Protocol. The total amount available for compensation for each incident is 750 million SDR, including the amounts payable under the 1992

\footnotetext{
13 Information accessed from: http://www.iopcfunds.org/about-us/legal-framework/1992-fundconvention-and-supplementary-fund-protocol/
} 
Conventions. ${ }^{14}$ These internationally-managed compensation fund schemes pay out on the basis of strict, no-fault requirement liability but with the quid pro quo proviso that claims from each incident are subject to strict upper limits on the total amount of compensation payable. They are arguably also examples of Ruggie Principle 29, calling for business enterprises to establish or participate in effective operational-level grievance mechanisms for individuals and communities who may be adversely impacted, to make it possible for grievances to be addressed early and remediated directly. ${ }^{15}$

However, even these international civil liability and compensation schemes do not engender formal international legal sanctions against the companies undertaking these activities. Moreover, the narrow focus of these international civil liability schemes should not be overlooked. The international oil spill compensation schemes, for example, only cover oil tanker cargo movements using this specific mode of transportation. Indeed, an experts workshop held at the Paris Oceanographic Institute on 30 March 2012 concluded that 'the international framework does not comprehensively address the safety and liability issues related to offshore oil activities.' 16

14 Information accessed from: http://www.iopcfunds.org/about-us/legal-framework/1992-fundconvention-and-supplementary-fund-protocol/

${ }^{15}$ See Ruggie Principle 29 and attached commentary, op. cit.

${ }^{16}$ Julien Richotte, 'Towards an international regulation of offshore oil exploitation, Report of the experts workshop held in Paris Oceanographic Institute on March 3oth 2012, IDDRI Working Paper, No.15 (July, 2012)18pp, at 12. 
Within the offshore exploration/production sector of the oil industry, one regional arrangement that has recently been amended in an Extraordinary General Meeting of the contractual parties on 28 October, 2013 to enter into force on $1^{\text {st }}$ January, 2014 is the 1975 Offshore Pollution Liability Agreement (OPOL). This is not an international convention but a private agreement between 16 (oil and gas company) operators in the offshore sector, adopted under the auspices of the Offshore Pollution Liability Association Ltd. ${ }^{17}$ OPOL imposes strict liability on operators of offshore facilities and guaranteed payment of compensation up to a limit currently set at US\$250 million per pollution incident. The parties to OPOL are the 16 operators of offshore facilities within the jurisdiction of any of the 'Designated States' to the Agreement. These include the UK, Denmark, Germany, France, Republic of Ireland, Netherlands, Norway, Isles of Man, Faroe Islands and Greenland. Cameron, however, observes that that this limit is not 'anywhere near sufficient'18 to tackle large releases of oil, such as in the Deepwater Horizon case. Moreover, he notes that although an international convention would be the ideal approach for the establishment of a global regime, the negotiation and implementation process would take years to complete, which would in turn lead to a 'long time period of uncertainty for operators and contractors, and ... diverse and unpredictable reactions from some regulatory bodies'. ${ }^{19}$

\footnotetext{
${ }^{17}$ Information on the Agreement and Association is accessible from:

http://www.opol.org.uk/index.htm

${ }^{18}$ Peter Cameron, Liability for Catastrophic Risk in the Oil and Gas Industry. International Energy Law Review, Vol.6 (2012) 207-219, at 211.

19 Cameron, at 218.
} 


\section{B. International Tribunal for the Law of the Sea reluctance to expand international responsibility}

Such oil spill compensation schemes, whether established by agreements between States, or through private, contractual-type liability agreements between corporate/industry representatives within each sector/region of the multinational oil industry, may prove to be the way forward on these issues. This is especially the case when there are continuing indications that both the States themselves and the international adjudication bodies they have established are reluctant to fully co-opt private actors within the doctrine of international State responsibility and liability for breaches of international norms. Instead, they seem to prefer emphasizing the due diligence requirement upon States to properly regulate any private economic actors that these States may licence/permit, for example, to operate mining activities in the deep sea-bed 'Area' beyond national jurisdiction. ${ }^{20}$ Thus, failing to exert sufficient due diligence over their licensees' activities might well result in State responsibility under international law, even if the environmental (or other types of) damage is actually caused by the private economic actor holding the licence/permit from the State concerned, according to a recent Advisory Opinion delivered by the Seabed Disputes Chamber of the International Tribunal on the Law of the Sea. ${ }^{21}$ On the other hand, if a

${ }^{20}$ Such activities are regulated under Part XI of the 1982 UN Convention on the Law of the Sea (UNCLOS)

${ }^{21}$ See: Responsibilities and Obligations of States sponsoring Persons and Entities with respect to Activities in the Area, Advisory Opinion of the Seabed Disputes Chamber of the International Tribunal for the Law of the Sea, ITLOS Case No.17, rendered: 1 February, 2011. Accessible at: http://www.itlos.org. For a comprehensive assessment of the implications of this Advisory Opinion for the progressive development of international law, see: Duncan French, 'From the depths: rich pickings of principles of sustainable development and general international law on the ocean floor - the Seabed 
sponsoring State has done all it can to reasonably discharge its due diligence duties vis-à-vis the regulation and supervision of its licensees then no international responsibility or liability will occur, despite the fact that damage has been occurred within the deep sea-bed Area. In such situations, the Chamber refused to consider extending even a residual form of international responsibility or non-fault liability to the sponsoring State concerned. Thus, ambiguity on this issue reigns.

While confirming the international responsibility of sponsoring States for ensuring that activities in the Area are carried out in conformity with Part XI of the Convention under Article 139, paragraph 2, of the Convention; ${ }^{22}$ the Chamber took the view that, 'in order for the sponsoring State's liability to arise, there must be a causal link between the failure of that State and the damage caused by the sponsored contractor.'23 The Chamber went on to state that ' $(t) h i s$ means that the sponsoring State's liability arises not from a failure of a private entity but rather from its own failure to carry out its own responsibilities. In order for the sponsoring State's liability to arise, it is necessary to establish that there is damage and that the damage was a result of the sponsoring State's failure to carry out its responsibilities. Such a causal link cannot be presumed and must be proven.' 24 After holding that the rules on the liability of sponsoring States set out in article 139, paragraph 2, of the 1982 Convention and in the related instruments are in line with the rules of customary international law on this issue, the

\footnotetext{
Disputes Chamber's 2011 advisory opinion', International Journal of Marine and Coastal Law, 26 (4) (2011) 525-568.

${ }^{22}$ Para.182 of the Advisory Opinion, ibid.

23 Para.181, ibid.

24 Para.184, ibid.
} 
Chamber referred to the International Law Commission (ILC) Articles on State Responsibility (hereinafter, 'ILC Articles') as follows: 'Under international law, the acts of private entities are not directly attributable to States except where the entity in question is empowered to act as a State organ (article 5 of the ILC Articles) or where its conduct is acknowledged and adopted by a State as its own (article 11 of the ILC Articles). (Thus) ..., the liability regime established in Annex III to the Convention and related instruments does not provide for the attribution of activities of sponsored contractors to sponsoring States.'25

Elaborating on the relationship between the liability of the contractor and of the sponsoring State, the Chamber refers to Annex III, article 22, of the 1982 Convention and observes that: 'No reference is made in this provision to the liability of sponsoring States. It may therefore be deduced that the main liability for a wrongful act committed in the conduct of the contractor's operations or in the exercise of the Authority's powers and functions rests with the contractor and the Authority, respectively, rather than with the sponsoring State. In the view of the Chamber, this reflects the distribution of responsibilities for deep seabed mining activities between the contractor, the Authority and the sponsoring State.'26 The Chamber then relies on its interpretation of the above provision and the ILC Articles to deny the possible application of joint and several liability as between the sponsoring State and its contractors, ${ }^{27}$ noting instead that 'the liability of the sponsoring State arises from its

\footnotetext{
25 Para.182, ibid.

${ }^{26}$ Para.200, ibid.

27 Para.201, ibid. According to the Chamber, the notion of joint and several liability arises where different entities have contributed to the same damage so that full reparation can be claimed from all
} 
own failure to carry out its responsibilities, whereas the contractor's liability arises from its own non-compliance. Both forms of liability exist in parallel. There is only one point of connection, namely, that the liability of the sponsoring State depends upon the damage resulting from activities or omissions of the sponsored contractor (see paragraph 181). But, in the view of the Chamber, this is merely a trigger mechanism. Such damage is not, however, automatically attributable to the sponsoring State.'28 Indeed, in the view of the Chamber, if the contractor has paid the actual amount of damage, as required under Annex III, article 22, of the Convention, then there would be no room for reparation by the sponsoring State. ${ }^{29}$

However, the Chamber also accepted that: ' $(\mathrm{t})$ he situation becomes more complex if the contractor has not covered the damage fully. It was pointed out in the proceedings that a gap in liability may occur if, notwithstanding the fact that the sponsoring State has taken all necessary and appropriate measures, the sponsored contractor has caused damage and is unable to meet its liability in full. It was further pointed out that a gap in liability may also occur if the sponsoring State failed to meet its obligations but that failure is not causally linked to the damage, ...' ${ }^{30}$ This raised the issue of whether the sponsoring State has 'a residual liability, that is, the liability to cover the damage not covered by the sponsored contractor', on which the Chamber noted, opinio juris among States was divided. ${ }^{31}$ In the view of the Chamber, 'the liability regime

\footnotetext{
or any of them, but the Chamber then asserts that this is not the case under the liability regime established in article 139, paragraph 2, of the Convention.

${ }^{28}$ Para.201, ibid.

29 Para.202, ibid.

30 Para.203, ibid.

${ }^{31}$ Para.203, ibid.
} 
established by article 139 of the Convention and in related instruments leaves no room for residual liability. As outlined in paragraph 201, the liability of the sponsoring State and the liability of the sponsored contractor exist in parallel. The liability of the sponsoring State arises from its own failure to comply with its responsibilities under the Convention and related instruments. The liability of the sponsored contractor arises from its failure to comply with its obligations under its contract and its undertakings thereunder. As has been established, the liability of the sponsoring State depends on the occurrence of damage resulting from the failure of the sponsored contractor. However, as noted in paragraph 182, this does not make the sponsoring State responsible for the damage caused by the sponsored contractor.' ${ }^{2}$ Thus, in situations where a contractor does not meet its liability in full while the sponsoring State is not liable under the Convention, the Chamber was of the view that the Authority may wish to consider the establishment of a trust fund to compensate for the damage not covered, drawing attention to article 235, paragraph 3 , of the Convention which refers to such possibility. 33

Apart from assessing the applicability of the Conventional rules on attribution of liability for damage to the deep sea-bed Area, the Chamber goes on to examine the general international law applicable to such situations, observing that: 'In the event that no causal link pertaining to the failure of the sponsoring States to carry out their responsibilities and the damage caused can be established, the question arises whether they may nevertheless be held liable under the customary international law rules on

\footnotetext{
32 Para. 204, ibid.

33 Para.205, ibid.
} 
State responsibility.'34 The Chamber then moved to consider whether customary international law may be used to fill the gap in the deep seabed liability regime established in Part XI of the Convention and related instruments, noting that Articles 139, paragraph 2, first sentence, and 304 of the Convention state that their provisions are 'without prejudice' to the rules of international law.35 After further noting that the efforts made by the ILC to address the issue of damages resulting from acts not prohibited under international law have not yet resulted in provisions entailing State liability for lawful acts, the Chamber again draws the attention of the Authority to the option of establishing a trust fund to cover such damages not covered otherwise. ${ }^{36}$ It will not have gone unnoticed that the solution mooted by the Chamber here is conceptually and practically similar to that which is already in place for tanker oil spill pollution compensation and liability for nuclear power generation accidents. While the Chamber does not elaborate on which of the entities concerned - whether the sponsoring States, or their licensees, or both - should contribute towards this trust fund, this option does allow for the possibility that the private economic actors undertaking deep sea-bed activities will be included within the proposed trust fund. These private economic actors will thus be captured by public international law in line with the risks their activities pose to the fragile deep sea-bed environment that is subject to the 'common heritage of mankind' principle.

\section{Litigation by Niger Delta Communities before Domestic US, Netherlands and UK Courts}

\footnotetext{
34 Para.183, ibid.

35 Para.208, ibid.

${ }^{6} 6$ Para.209, ibid.
} 
A further legal response to the alleged damage caused by the overseas activity of multinational oil companies is aimed at rendering them accountable before the domestic courts of their own, home jurisdictions rather than through the application of international regimes. Traditionally, the main legal obstacles to such litigation by alleged victims of multinational oil companies operating abroad before the domestic courts of the home jurisdiction of these companies are two-fold: First, there is a presumption under international law against the extra-territorial exercise of jurisdiction by domestic courts, also known as the forum non conveniens rule that normally prevents them from adjudicating on claims that arise from foreign jurisdictions. Second, there is the company law doctrine of the 'corporate veil' which provides that the liability of a subsidiary company should not be visited upon the parent company of that subsidiary, especially when the parent company is resident in a different national jurisdiction. Both these doctrines continue to present difficulties for attempts to enforce accountability for multinational oil company activities within foreign jurisdictions. It should also be noted that even if/when the extra-territorial jurisdiction and corporate veil issues are overcome, any municipal court decisions in the home State jurisdictions of the parent company must be accepted by the local courts in the jurisdictions of the subsidiary company for enforcement against them.

Three recent cases within different domestic jurisdictions, namely, the USA, the Netherlands and the UK, serve to focus attention on these continuing legal issues arising from activities conducted by multinational oil companies operating beyond their home jurisdictions. In each of these cases, representative individuals or groups from Niger Delta communities claimed compensation from the Shell oil multinational corporate group. The analytical arrangement of these cases reflects first, the upholding in Kiobel $v$ Royal Dutch (Shell) Petroleum of the presumption against the extra- 
territorial application of the US federal Alien Torts Statute (ATS) by the US Supreme Court. This is followed by the Akpan $v$ Royal Dutch Shell \& Shell Nigeria case, where a Dutch municipal court set aside the presumption against extra-territorial jurisdiction to hold the Nigerian subsidiary company of Shell liable under the common law tort of negligence but declined to lift the corporate veil and implicate the Royal Dutch Shell parent company (in the Netherlands) for this breach of a duty of care amounting to negligence by its Nigerian subsidiary. Finally, continuing litigation in the Bodo Community and Shell Petroleum Development Company (SPDC) of Nigeria (Shell Nigeria) case confirms the extra-territorial application of Nigerian law by the High Court in the UK to adjuciate claims of tortious liability against SPDC/Shell Nigeria but has not yet yielded a final decision on total damages and costs.

In the first of these cases, namely, the US Supreme Court decision in the Kiobel $v$ Royal Dutch (Shell) Petroleum Co. on 17 April 2013,37 the plaintiff(s) from the Ogoniland region in Nigeria alleged that the multinational corporate defendant (Royal Dutch Shell), which also has major operations in the US, aided and abetted human rights abuses by the Nigerian government. However, the Supreme Court ruled against the extra-territorial application of the 1789 US Alien Torts Statute (ATS) and disallowed liability claims against the US-based corporate entities of Shell to the SPDC/Shell Nigeria. ${ }^{8}$ As Wuerth succinctly observes, '(o)n the facts of the case - the relevant conduct took place within the territory of a foreign sovereign, the claims did not "touch and concern" U.S. territory, and the foreign defendants had no more than a "corporate presence" in the United States - the Court held that the presumption was not

\footnotetext{
37 US Supreme Court, 133 (US) S.Ct. 1659 (2013) 17 April, 2013.

${ }^{38}$ Ibid., at 1668-69.
} 
overcome.'39 Thus, 'the Court was unanimous in deciding that the claims lacked sufficient connection with the United States.'40 While the Supreme Court decision in Kiobel confirming the lack of extra-territorial application of the ATS to claims originating from Nigeria cannot be directly compared with the Netherlands municipal court decision of Akpan $v$ Royal Dutch Shell \& SPDC/Shell Nigeria rendered on 30 January, 2013 in The Hague, Netherlands, ${ }^{41}$ they are linked together by the original nationalities of the claimants (Nigeria) and the corporate defendants (Royal Dutch/Shell multinational group) in both cases.

The Akpan case, which will be covered in more detail here due to its relative lack of publicity, was initially brought against both the parent Royal Dutch Shell company, as well as its subsidiary in Nigeria - SPDC/Shell Nigeria, for its neglect of an oil spill that caused damage to adjoining farm land and fishing ponds in the Niger Delta region. According to Bekker, this lawsuit was the first time a Dutch multinational company has been sued before a civil court in the Netherlands for allegations of pollution

\footnotetext{
39 Ingrid Wuerth, 'Kiobel v. Royal Dutch Petroleum Co.: The Supreme Court and the Alien Tort Statute', American Journal of International Law, Vol. 107, No. 3 (July, 2013) 601-621, at 603.

40 Ibid.

${ }^{41}$ LJN: BY9854, Rechtbank 's-Gravenhage , C/o9/337050/HA ZA 09-1580, 30 January, 2013. An English translation of this judgment is accessible from: http://www1.milieudefensie.nl/englishpublications/Judgment\%20courtcase\%20Shell\%20in\%20jurisdiction\%20motion\%20Oruma.pdf
} 
damage caused by its subsidiary company abroad. $4^{2}$ In the Akpan case, Nigerian farmers and fishermen victims from the neighbouring villages of Goi, Oruma and Ikot Ada Udo, lost their livelihoods when a leaking SPDC oil wellhead polluted their fields and fishing ponds. The (representative) individual claimant, Akpan is a Nigerian farmer and fisherman who supported himself by exploiting land and fish ponds near Ikot Ada Udo in Akwa Ibom State in Nigeria. He was supported in his claim by Vereniging Milieudefensie, a Dutch NGO, 'whose objective is the worldwide promotion of environmental care.'43 The joint claims of Akpan and Milieudefensie relate to two specific oil spills in 2006 and 2007 from an oil well, the wellhead of which was capped above ground but tampered with, causing the two spills. Following some initial remedial work in 2007 , the wellhead was finally sealed off against sabotage by means of a concrete plug. 44 The joint plaintiffs brought claims against both the Royal Dutch Shell plc parent company and the SPDC/Shell Nigerian subsidiary before a court in The Hague, Netherlands, inter alia, claiming compensation and an order for SPDC to clean-up the remaining oil contamination. In response, SPDC/Royal Dutch Shell contested the jurisdiction of the Dutch courts to adjudicate on the above issues, requested that the court declare that it has no jurisdiction over the claims against the SPDC and moreover, that the plaintiffs were abusing the relevant Dutch law by initiating proceedings against Royal Dutch Shell, the parent company of SPDC/Shell Nigeria. A further legal issue concerned the standing of the Dutch NGO as a joint

\footnotetext{
${ }^{42}$ See: Pieter Bekker, 'Landmark ruling by Dutch court against Shell Nigeria', Centre for Energy, Petroleum, and Mineral Law and Policy (CEPMLP), University of Dundee. Accessible from CEPMLP Gateway website at: http://www.dundee.ac.uk/cepmlp/gateway/index.php?news=32271 ${ }^{43}$ Akpan v Royal Dutch Shell plc/SPDC (Nigeria) op. cit., at para.2.4 (unofficial English translation) 44 Para.2.11 of Akpan (2014) ibid.
} 
plaintiff, alongside Akpan as a representative claimant from the affected Nigerian communities, in relation to the claims for environmental damage in Nigeria.

The Akpan $v$ Royal Dutch Shell/SPDC decision thus confirms the jurisdictional, corporate veil and domestic legal enforcement challenges referred to above when attempting to invoke liability against the Netherlands-based, Royal Dutch Shell parent company for the activities of its subsidiary company - SPDC, based in Nigeria. 45 The jurisdictional challenge alluded to here relates to the difficulty that bringing an extraterritorial claim presents for most national legal systems around the world. On the other hand, an amicus curiae submission by a group of Dutch international lawyers to the Kiobel $v$ Royal Dutch Shell case before the US Supreme Court concluded as follows: 'Dutch case law is therefore incompatible with any alleged rule of customary international law prohibiting the exercise of jurisdiction by domestic courts over claims such as those pursued by the Petitioners here. To the contrary, recent Dutch case law suggests that such claims are indeed recognized by the courts.' 46 The collective

45 The parent-subsidiary corporate relationship was described by The Hague court as follows: 'Defendants SPDC and RDS are legal entities that are part of the Shell Group. RDS is headquartered in The Hague (Netherlands); since 20 July 2005, it has been at the head of the Shell Group. Through subsidiaries, RDS holds all shares in its sub-subsidiary, SPDC. SPDC is the Nigerian legal entity that conducts the oil production operations in Nigeria for the Shell Group.', para.2.2. of Akpan (2014) op. cit.

${ }^{46}$ Brief of Professor Alex-Geert Castermans (Leiden University), Professor Cees Van Dam (Utrecht University), Dr. Liesbeth Enneking (Utrecht University), Dr. Nicola Jägers (Tilburg University), Professor Menno Kamminga (Maastricht University), as Amici Curiae in support of the Petitioners, Esther Kiobel, et al., v. Royal Dutch Petroleum Co., et al., Respondents, June 13, 2012. No. 10-1491. Accessible at: 
view of these Dutch University academics was confirmed in the Akpan case. In a significant interlocutory judgment on its jurisdiction on 24 February 2010,47 The Hague district court unequivocally affirmed that 'the forum non conveniens restriction no longer plays any role in today's private international law.'48 Moreover, The Hague district court found that it had jurisdiction over the claims against both corporate defendants, namely, the Shell subsidiary in Nigeria, and the Shell parent company in The Netherlands, because of the close connection between both these entities, such that a joint hearing was justified for reasons of efficiency. 49 The Dutch court therefore dismissed Shell's arguments, concluding that it had jurisdiction over both SPDC and Royal Dutch Shell on these matters. $5^{\circ}$ In passing, it should be noted that the court, and indeed the relevant Dutch and EU laws that it based its decision on jurisdiction in this case, may be said to be fulfilling Ruggie Principle 26, which calls for consideration of ways to reduce legal, practical and other relevant barriers that could lead to a denial of access to effective domestic judicial remedies for addressing business-related human rights abuses.

Following this determination on its jurisdiction, The Hague court then ruled that the applicable law in these proceedings would be Nigerian law, ${ }^{1}$ noting in passing that

http://www.nipr-online.eu/upload/documents/20120820To40709-

Dutch\%2olegal\%20scholars\%20Kiobel\%20amicus\%2obrief.pdf

${ }^{47}$ LJN BM1469, accessible at: http://www.rechtspraak.nl

${ }^{48}$ Akpan $v$ Royal Dutch Shell plc/SPDC (Nigeria) op. cit., at para.4.6 (unofficial English translation)

49 Ibid., at para.4.1.

5o Ibid., at para.4.7.

${ }^{51}$ Ibid., at para.4.9. 
Nigerian law is a common law system based on English law. 52 the court had previously observed that '.. under certain circumstances, based on Nigerian law, the parent company of a subsidiary may be liable based on the tort of negligence against people who suffered damage as a result of the activities of that (sub-) subsidiary.'53 Next, the admissibility of Milieudefensie's claims against the RDS and SPDC/Shell Nigeria as a separate claimant were considered. Here, the court held that Milieudefensie's claims clearly rose above the individual interests of Akpan, and that remediating the soil, cleaning up the fish ponds, purifying the water sources and preparing an adequate contingency plan for future responses to oil spills - if ordered - would benefit not only Akpan, but the rest of the community and the environment in the vicinity of Ikot Ada Udo, as well.54 Moreover, the court considered that Milieudefensie's campaigns aimed at stopping environmental pollution in the production of oil in Nigeria were designed to promote the environmental interests in Nigeria.55 Finally, the court held that such local environmental damage abroad would fall within the description of Milieudefensie's objective in its articles of association, i.e., to promote environmental protection worldwide. 56

However, while the court initially ruled in favour of the admissibility of the Dutch NGO's claims to defend environmental interests in Nigeria before the courts in the Netherlands, 57 it ultimately rejected the Dutch NGO's claims in substance because oil

\footnotetext{
${ }^{2}$ Ibid., at para.4.10.

53 Ibid., at para.4.3.

54 Ibid., at para.4.11.

55 Ibid., at para.4.12.

${ }^{56}$ Ibid.

57 Ibid., at para.4.14.
} 
pollution in Nigeria does not directly affect Milieudefensie's interests and did not give rise to an actionable claim by the Dutch environmental NGO based in Amsterdam, the Netherlands under Nigerian law. The fact that under the relevant Dutch law, Milieudefensie can protect the interests of third parties in law does not mean that any damage of those third parties can be considered to be damage to Milieudefensie itself. $5^{8}$ The Hague court further noted that under Nigerian common law, there was no proximity between SPDC in Nigeria and Milieudefensie in Amsterdam for any damage that occurred in Nigeria near Ikot Ada Udo. Thus, Shell et al had not violated any duty of care in respect of Milieudefensie and the court dismissed the claims by and for Milieudefensie. 59

Moving onto the issue of Royal Dutch Shell (RDS) parent company liability for its subsidiary, SPDC/Shell Nigeria, in its final rulings of 30 January 2013, the court dismissed all claims against the parent company - RDS, because under Nigerian law a parent company in principle is not obligated to prevent its subsidiaries from injuring third parties abroad and in the present case there were no special reasons to deviate from the general rule. ${ }^{60}$ Specifically, Milieudefensie had argued that by making the prevention of environmental damage as a result of the activities of its operating companies - including SPDC in Nigeria - a key objective of its well-publicized overall corporate policy, RDS had assumed a duty of care regarding the manner in which SPDC's oil operations in Nigeria are conducted. In this regard, the RDS-SPDC/Shell Nigeria, parent-subsidiary, corporate relationship was compared with that in the

\footnotetext{
${ }^{8}$ Ibid., at para.4.35.

59 Ibid.

6o Bekker op. cit., referring to para.4.26 of the Judgment.
} 
Chandler $v$ Cape plc case before the UK Court of Appeal.61 However, The Hague court found that 'the special relation or proximity between a parent company and the employees of its subsidiary that operates in the same country cannot be unreservedly equated with the proximity between the parent company of an international group of oil companies and the people living in the vicinity of oil pipelines and oil facilities of its (sub-) subsidiaries in other countries.'62 Moreover, 'the duty of care of a parent company in respect of the employees of a subsidiary that operates in the same country further only comprises a relatively limited group of people, whereas a possible duty of care of a parent company of an international group of oil companies in respect of the people living in the vicinity of oil pipelines and oil facilities of (sub-) subsidiaries would create a duty of care in respect of a virtually unlimited group of people in many countries.' 63 Thus, The Hague court held that a similar duty of care to that which was found by the UK Court of Appeal in Chandler could not be as reasonably, fairly and justly found in relation to RDS and SPDC/Shell Nigeria. ${ }^{64}$ The Royal Dutch Shell group of (parent) companies was therefore effectively absolved from the liability of its Nigerian-based subsidiary - SPDC/Shell Nigeria - for its lack of effective action to prevent oil spill damage from wellhead leaks resulting from sabotage by third persons. ${ }^{65}$

\footnotetext{
${ }^{61}$ Ibid., at para.4.27; see Chandler $v$ Cape plc, CA [2012] EWCA Civ 525, on appeal from the High Court of Justice (Queens Bench Division) Wyn Williams J [2011] EWHC 951 (QB)

62 Ibid., at para.4.29.

${ }^{63}$ Ibid.

64 Ibid.

${ }^{65}$ Ibid., at para.4.34.
} 
On the other hand, The Hague court held that it was fair, just and reasonable to rule that SPDC had a specific duty of care in respect of the people living in the vicinity of the oil wellhead, especially fishermen and farmers like Akpan, to take reasonable security measures against sabotage. ${ }^{66}$ As an operator acting reasonably, SPDC could have properly secured the oil wellhead at relatively low cost, which would in turn have considerably reduced the risk of sabotage. This lead the court to the conclusion that in this specific case, SPDC had violated its duty of care in respect of Akpan and committed a specific tort of negligence. 67 As there was a causal link between the violation of this specific duty of care by SPDC and the damage suffered by Akpan, SPDC was liable to pay Akpan compensation for this damage. ${ }^{68}$ However, this ruling then raises the enforcement issue noted above. A continuing legal question is whether this municipal Dutch court decision on liability and compensation against the SPDC/Shell Nigeria can be enforced and complied with in Nigeria, especially given the lack of compliance by SPDC to domestic Nigerian court decisions in other Niger Delta cases of a similar nature in the past. ${ }^{69}$

Turning to the third domestic jurisdiction in which similar lawsuits have been brought by representatives of local Nigerian communities against SPDC/Shell Nigeria; in The

\footnotetext{
${ }^{66} \mathrm{Ibid}$., at para.4.44.

${ }^{67}$ Ibid., at para.4.45.

${ }^{68}$ Ibid.
}

69 See: Corporate liability in a new setting: Shell and the changing legal landscape for the multinational oil industry in the Niger Delta, especially Appendix II: Remedying Oil Spills in the Niger Delta: Elements for Assessing Responsibility, Report of the Essex Business and Human Rights Project, 118pp, at 63-109, published on 10 December, 2012. Accessible at: http://www.essex.ac.uk/ebhr/documents/niger_delta_report.pdf 
Bodo Community $v$ The Shell Petroleum Development Company of Nigeria Ltd., representatives of the community brought claims before the UK High Court, on behalf of some 15,000 or more Nigerians living in the neighbouring Bodo and Gokana areas. $7^{70}$ These claims for compensation were initially lodged against both RDS and SPDC/Shell Nigeria for oil spills that have polluted the creek, rivers and waterways as well as the mangrove areas in the Bodo region. The damage is estimated to have affected an area of $20 \mathrm{~km}^{2}$ in the Gokana Local Government Area of Rivers State in Nigeria. SPDC has admitted liability for damage resulting from two major oil spills in 2008/9, in particular to the waterways used by this fishing community in the Niger Delta. The amount of oil spilt is estimated to be as large as the spill following the Exxon Valdez disaster in Alaska in 1989 and the amount of coastline affected is said to be equivalent to the damage done following the BP Deepwater Horizon disaster in the Gulf of Mexico in 2010 (considered below). However, this admission of liability is currently subject to further litigation over the full extent of the oil spillages and their timing. ${ }^{71}$

Proceedings against RDS and SPDC began in the UK High Court on 6 April, 2011. However, in August 2011, Shell was reported to have accepted legal responsibility for the two spills, stating, inter alia, that: 'SPDC accepts responsibility under the Oil Pipelines Act for the two oil spills both of which were due to equipment failure. SPDC acknowledges that it is liable to pay compensation - to those who are entitled to receive

\footnotetext{
70 'Particulars of Claim', Claim No. HQ11X01280, in the High Court of Justice, Queen's Bench Division, 23 March, 2012.

${ }^{71}$ [2014] EWHC 1973 (TCC) 20 June, 2014, per Akenhead J., at para.7, with a final decision forthcoming in 2015 .
} 
such compensation. ${ }^{72}$ In an agreement between the parties, SPDC has agreed to formally accept liability and concede to the jurisdiction of the UK courts, which means that the claim against RDS, the parent company of SPDC in Nigeria, has ceased.73

In the subsequent High Court adjudication on the extent of SPDC liability, a similar legal finding to the duty to prevent possible sabotage of the oil wellhead that was held by the Dutch court in the Akpan case has also emerged in the Bodo Community litigation before the UK High Court. This relates to the extent to which the word 'protect' in the relevant Nigerian legislation (Section 11(5)(b) of the Oil Pipelines Act, 1990) involves an additional obligation to that of 'maintain or repair' the pipeline concerned. As Akenhead J held, 'The real issue revolves around whether the required protection gives rise to any liability separate to the maintenance and repair obligation, and, if so, how far the scope of protection goes.' ${ }^{34}$ He goes on to state that: 'Whilst I do not consider that the word "protect" is exactly and necessarily synonymous with maintenance or repair (of a pipeline), logic suggests that they may well overlap in practice; ... the usual definitions (of 'protect') can be seen to be closer to shielding from danger, injury or change and keeping safe and taking care of. ... (I)t is my judgment that the protection requirement within Section 11(5)(b) involves a general shielding

\footnotetext{
${ }^{72}$ See John Vidal, 'Shell accepts liability for two oil spills in Nigeria', Wednesday 3 August 2011. Accessed from The Guardian newspaper (UK) website, at:

http://www.guardian.co.uk/environment/2011/aug/03/shell-liability-oil-spillsnigeria? $\mathrm{INTCMP}=\mathrm{SRCH}$

${ }^{73}$ See: Shell accepts responsibility for oil spill in Nigeria, 3 August 2011, Accessed from: http://www.leighday.co.uk/News/2011/August-2011/Shell-accepts-responsibility-for-oil-spill-in-Nige 74 [2014] EWHC 1973 (TCC) 20 June, 2014, per Akenhead J., at para.92.
} 
and caring obligation. $75 \mathrm{He}$ then concludes that: '... neglect by the licensee in the protection of the pipeline (as defined above) which can be proved to be the enabling cause of preventable damage to the pipeline by people illegally engaged in bunkering which causes spillage could give rise to a liability; ...76 Thus, in both these cases Akpan before The Hague court, based on the common law tort of negligence \& Bodo before the High Court, based on interpretation of the relevant statue - it has been determined that it is the failure to protect/prevent the relevant oil wellhead/pipeline from acts of sabotage that cause oil spill damage that can give rise to liability on the part of the operating oil company.

\section{State Re-intervention to Ensure Appropriate Corporate Responses to Oil Spills: International 'Best Practice'?}

Having outlined and assessed the legal challenges faced at both international and domestic jurisdiction levels in relation to asserting accountability for multinationmal oil companies operating on foreign jurisdictions, this next Part of this study will provide two examples of (host) State-induced corporate responses to oil spill clean-up, remediation and compensation. Significantly, these State 'enforcement' actions against two different, so-called 'super major' multinational oil companies took place prior to the ultimate domestic judicial decisions on their corporate liability for these major oil spills. These two examples: the BP/US and Total/French/EU responses to

\footnotetext{
75 Ibid.

${ }^{76}$ Ibid., at para.93.
} 
the Deepwater Horizon and Erika oil spills, respectively, arguably represent international 'best practice' in this field. They are detailed here as follows:

\section{A. Deepwater Horizon/Macondo offshore oil well spill (BP/US)}

Following the Gulf of Mexico Deepwater Horizon/Macondo offshore oil well disaster on 20 April 2010,77 the Obama Presidential Administration, through the US Coast Guard, and without in any way relieving other responsible parties of liability, directed British Petroleum (BP) as the designated operator of the well, to establish a single claims facility for all Responsible Parties to centralize claims processing for claimants. As an initial response to its acceptance corporate responsibility and liability, BP announced on June 16, 2010, that it would create a USD $\$ 20$ billion escrow account to satisfy claims resolved by the Gulf Coast Claims Facility (GCCF) and certain other claims, including natural resource damages. BP established an irrevocable Trust (for the announced escrow account) on August 6, 2010, designating three trustees with fiduciary responsibility to collect promised contributions from BP and make disbursements to permitted categories of beneficiaries. It committed BP to fund the

\footnotetext{
77 On 20 April 2010, an explosion on an ultra deepwater semi submersible offshore rig, the 'Deepwater Horizon' killed 11 crewmen and ignited a fireball seen 56 kilometres (35 miles) from the explosion. After 36 hours of burning, the rig sank on 22 April, leaving the Macondo well it had drilled in the Gulf of Mexico gushing onto the ocean bed and causing the largest offshore oil spill in the history of the United States. The spillage continued for 152 days until 19 September 2010, when BP confirmed the completion of cementing operations to prevent further oil from spilling from the Macondo Prospect well to which the Deepwater Horizon was attached when it exploded. The Deepwater Horizon was leased by BP America Production Company (BP) as part of the Macondo project. For an initial discussion of the liability issues arising from this disaster, see Ruwantissa Abeyratne, 'The Deepwater Horizon Disaster - Some Liability Issues', 35 Tulane Maritime Law Journal (Winter, 2010) 125.
} 
Trust on a quarterly basis over three and a half years for a total of USD $\$ 20$ billion to be paid into the Trust until 2014. The funding schedule for the escrow account agreed to by the administration and BP was for contributions by BP of $\$ 5$ billon a year for 4 years. BP later confirmed that the funding schedule would include an initial deposit of $\$ 3$ billion, which was made on August 9, 2010, with an additional deposit of $\$ 2$ billion in the fourth quarter of 2010 and $\$ 1.25$ billion a quarter until the entire $\$ 20$ billion has been deposited. The Trust is to pay some OPA-compensable claims (under the US federal Oil Pollution Act (OPA) of 1990) and some other claims for personal injuries that are not OPA-compensable, but for which BP would be liable under other US federal or state laws, such as the Jones Act or state oil pollution acts. Under Section 1002 of OPA, 1990 each person responsible for a vessel or a facility from which oil is discharged, or which poses the substantial threat of a discharge of oil, into or up on the navigable waters or adjoining shorelines or the exclusive economic zone is liable for the removal costs and damages. BP established the GCCF to provide a mechanism for individuals and businesses to file claims for costs and damages incurred as a result of the Deepwater Horizon oil spill. Under the OPA 1990, these claims can cover damage to natural resources, including clean-up and remediation costs for wildlife habitats and ecosystems. ${ }^{8}$ The GCCF began operations and started accepting claim forms on August 23, 2010. The GCCF, administered by Kenneth R. Feinberg, draws funds from the Trust to pay claims.79

\footnotetext{
${ }^{78} 33$ U.S.C. para.2701(20) \& para.2702(b)(2)(A).

79 Based on information drawn from the United States Government Accountability Office (GAO), Study/Report on Deepwater Horizon Oil Spill: Preliminary Assessment of Federal Financial Risks and Cost Reimbursement and Notification Policies and Procedures, GAO-11-90R Oil Spill Liability Trust Fund. 57pp, in Enclosure I, at p.14. (Washington, DC: 12 November, 2010) Accessible from GAO website at: http://www.gao.gov.
} 
Thus, liability for the damage caused is being enforced at the domestic US (federal and state) jurisdictional level. Indeed, as noted above, BP has already been subjected to unprecedented US federal government fines totalling US $\$ 4.5$ billion. ${ }^{80} \mathrm{BP}$ is facing further, multiple US state and local government, as well as civil liability compensation claims from individuals who suffered damage from the oil spill. Indeed, no sooner had BP agreed to the record US federal government fine, when the (US) state governments of Louisiana, Alabama, Mississippi, Florida and most recently, Texas made separate claims amounting to a further US\$34 billion in total. 81

This swift admission of BP's overall corporate responsibility, ${ }^{82}$ coupled with its advance acceptance of an initial multi-billion US dollar liability for the Deepwater

80 BP's total of $\$ 4.5$ billion in federal penalties includes $\$ 2.4$ billion for the National Fish and Wildlife Foundation, a $\$ 1.256$ billion criminal fine and $\$ 350$ million for the National Academy of Sciences - all payable over five years - and a $\$ 525$ million civil penalty to the Securities and Exchange Commission. See Reuters (UK) news agency report, 'U.S. judge okays BP plea, $\$ 4$ billion penalty in Gulf oil spill.' Accessible at: http://uk.reuters.com/article/2013/01/29/uk-bp-spill-idUKBRE9oSoWN20130129

${ }^{81}$ See: 'Deepwater Horizon Oil Spill - Texas Becomes 5th Gulf State to File Lawsuit Against BP', Accessible at: http://claimscomp.com/bp-transocean-are-sued-by-texas-over-2010-deepwaterhorizon-oil-spill/

${ }^{82}$ BP's overall corporate responsibility for the Deepwater Horizon oil rig explosion and consequent loss of life, as well as environmental damage from the resulting oil spill has now been confirmed by findings in the final investigation report of the Bureau of Ocean Energy Management, Regulation and Enforcement (BOEMRE) of the US Federal Ministry of the Interior into the disaster: Report Regarding the Causes of the April 2O, 2010 Macondo Well Blowout, released on 14 September, 2011. Accessible from:

http://www.boemre.gov/pdfs/maps/DWHFINAL.pdf 
Horizon spill and moreover, establishment of a formal institutional framework for management of compensation claims in the form of the GCCF, can be favourably contrasted with the decades-old struggle to engage Shell (and other IOCs) with their responsibility and liability for oil spills of in the Niger Delta. Many NGOs and commentators have drawn attention to the gulf of difference between efforts to cleanup, remediate and compensate oil pollution damage in the recent Deepwater Horizon spill, as opposed to the continuing lack of such efforts over spills of similar overall magnitude in the Delta region over a greater length of time. ${ }^{83}$ For example, a local civil society organisation, the Human Rights Writers' Association of Nigeria (HURIWA), not only applauded a landmark July 2010 Nigerian Federal High Court decision requiring SPDC pay the Ejama-Ebubu community the sum of N15.4 billion as special and punitive damages, but also advised the defaulting SPDC/Shell Nigeria to pay the damages in line with 'international best practices' (sic), drawing a lesson from the response of both the White House and Capitol Hill to the Deepwater Horizon disaster in the United States. ${ }^{84}$ Indeed, Milieudefensie, the Dutch chapter of the Friends of the Earth (FOE) environmental NGO network, has labelled the wide disparity between the

\footnotetext{
${ }^{83}$ See: 'Nigeria's agony dwarfs the Gulf oil spill. The US and Europe ignore it: The Deepwater Horizon disaster caused headlines around the world, yet the people who live in the Niger delta have had to live with environmental catastrophes for decades', by John Vidal, environment editor, The Observer (UK) newspaper, Sunday 30 May 2010.

84 See: Davidson Iriekpen, 'Oil Spill: Rights Group Hails Court Ruling against Shell', 13 Jul 2010. Accessible from:

http://www.thisdaylive.com/articles/oil-spill-rights-group-hails-court-ruling-against-shell/83519/
} 
BP and Shell responses to the Deepwater Horizon and Niger Delta spills, respectively, as 'Shell's double standard.' 85

\section{B. Erika oil tanker spill (Total/France/EU)}

A second example of voluntary corporate efforts at clean-up, remediation and compensation is evidenced from the Total oil company response following the Erika oil tanker spill off the French coast of Brittany. ${ }^{86}$ Total (as the oil cargo owner) and several ship (worthiness) classification societies were sued by French local authorities (and wildlife NGOs) for the clean-up and remediation costs and obtained an initial order for Total to pay out millions of Euros in clean-up and remediation costs. Faced with French government and public pressure, Total committed these sums in advance of its appeals against this initial order, and even when it won the appeal, did not take steps to recoup it outlay for the Erika clean-up. The facts and legal issues arising from the Erika incident are summarised below:

On 12 December 1999, the 25-year old Maltese-registered oil tanker, Erika (19 666 gross tonnage) broke in two in the Bay of Biscay, some 60 nautical miles off the Brittany coast, western France releasing tonnes of heavy fuel oil into the Atlantic. All members of the crew were rescued by the French maritime rescue services. Some

\footnotetext{
${ }^{85}$ See: 'Royal Dutch Shell and its sustainability troubles: Background report to the Erratum of Shell's Annual Report 2010', May 2011. This report was prepared on behalf of Milieudefensie (Friends of the Earth Netherlands) by Albert ten Kate, at pp.8-9. Accessible at:

http://milieudefensie.nl/publicaties/rapporten/shell-background-report

86 See: Erika Oil Tanker Break-up \& Spill Incident, France, 12 December 1999, Report of the International Oil Pollution Compensation Funds (IOPC) organization, updated 9 May 2011. Accessible from: http://www.iopcfund.org/erika.htm
} 
400 kilometres of shoreline were affected by oil. Although the removal of the bulk of the oil from shorelines was completed quite rapidly, considerable secondary cleaning to remove residual contamination was still required in many areas. Operations began in spring 2001 and was mostly completed by November, 2001. More than 250000 tonnes of oily waste were collected from shorelines and temporarily stockpiled. Total SA, the French (major) oil company that owned the oil cargo of the Erika, engaged a contractor to deal with the disposal of the recovered waste and this operation was completed in December 2003. According to Total, immediately following the sinking, the company established the Atlantic Coast Task Force and spent more than $€ 200$ million to remedy the consequences of the oil spill through clean-up of hard-to-access areas of the coastline, pumping out the cargo remaining in the wreck and treatment of waste collected along the coast. ${ }^{87}$

Initial compensation claims were settled by the international oil pollution compensation scheme established by States, as described above. The maximum amount of funds available for compensation under the applicable international tanker oil spill compensation scheme, namely, the 1992 Civil Liability Convention (CLC) and the 1992 Fund Convention, for the Erika incident was 135 million SDR (Special Drawing Rights), then equivalent to around $€ 185$ million. Both the French State and by Total SA also made undertakings to 'stand last in the queue' for the final redemption of oil spill clean-up and remediation costs. ${ }^{88}$ The different categories of claims allowed include the following headings: property damage and loss of tourism, damage to

\footnotetext{
${ }^{87}$ See: 'Erika: Measures taken by Total', accessible from Total website at: http://www.total.com/en/about-total/special-reports/erika/measures-taken-by-total-922664.html 88 IOPC Annual Report 2008, at p.78.
} 
mariculture and oyster farming, shellfish gathering, fishing boats, fish and shellfish processors, and the costs of clean-up operations. Following the Erika and Prestige incidents, a Supplementary Fund Protocol to the 1992 Fund Convention was adopted in 2003 and entered into force in 2005, providing (for those IOPC Member States who chose to make additional contributions) a much higher limit of compensation (Supplementary Fund Protocol). ${ }^{89}$

Aside from the clean-up and remediation costs incurred by Total in the immediate aftermath of the incident, both criminal charges and civil liability claims were also brought against Total in the Criminal Court in Paris. A number of claimants, including the French Government and several local authorities, joined the criminal proceedings as civil parties, claiming compensation totalling €400 million. In its judgment, delivered in January, 2008, the Criminal Court held the following four parties criminally liable for the offence of causing pollution, the representative of the shipowner (Tevere Shipping), the president of the management company (Panship Management and Services Srl), the classification society (RINA) and Total SA. The Paris Criminal Court of First Instance also recognised a) the civil right to compensation for damage to the environment for a local authority with special powers for the protection, management and conservation of a territory, as well as b) the judgment recognised the right of an environmental protection association to claim compensation, not only for the moral damage caused to the collective interests which it was its purpose to defend, but also for the damage to the environment which affected the collective interests which it had a statutory mission to safeguard. Regarding these

\footnotetext{
${ }^{89}$ See IOPC Annual Report 2010, at p.6. Accessible from:

http://www.iopcfund.org/npdf/AR2010_e.pdf
} 
civil liabilities, the judgment held the four parties jointly and severally liable for the damage caused by the incident and awarded claimants in the proceedings compensation for economic losses, damage to the image of several regions and municipalities, moral damages and damages to the environment. Moreover, the judgment considered that Total SA could not avail itself of the benefit of the channelling provision of Article III.4(c) of the 1992 CLC, $9^{\circ 0}$ since the Court held it was not the charterer of the Erika, as the charterer was one of Total SA's subsidiaries. The judgment considered that the other three parties, RINA in particular, were also not protected by the channelling provisions of the 1992 CLC, since they did not fall into the category of persons performing services for the ship under Article III.4(b). ${ }^{91}$

The judgment concluded that French domestic law should be applied to the four parties and that therefore the four parties had civil liability for the consequences of the incident. The compensation awarded to the civil parties by the Criminal Court of First Instance was based on national law. The Court held that the 1992 Conventions did not deprive the civil parties of their right to obtain compensation for their damage in the Criminal Courts and awarded claimants in the proceedings compensation for economic loss, damage to the image of several regions and municipalities, moral

${ }_{90}$ Article III.4 states, inter alia, that 'no claim for compensation for pollution damage may be made against the owner otherwise than in accordance with this Convention. Subject to paragraph 5 of this Article, no claim for compensation for pollution damage under this Convention or otherwise may be made against: ... (c) any charterer (how so ever described, including a bareboat charterer), manager or operator of the ship; ...'

${ }_{91}$ Article III.4 states, inter alia, that '... no claim for compensation for pollution damage under this Convention or otherwise may be made against: ... (b) the pilot or any other person who, without being a member of the crew, performs services for the ship;...' 
damages and damages to the environment. The Court assessed the total damages in the amount of $€ 192.8$ million, including $€ 153.9$ million for the French State. The four parties held liable, including Total appealed against both the criminal and civil liability aspects of this judgment. However, without admitting its liability, Total SA nevertheless made voluntary payments in full and final settlement to the plaintiffs who accepted them, including to the French local and State governments, totalling €171.5 million. Accordingly, Total estimates that it has spent over $€_{370}$ million in total to clean-up, remediate and compensate for the damage resulting from the Erika incident.

In its judgment on 30 March 2010, the Court of Appeal of Paris confirmed the judgment of the Criminal Court of First Instance, and held, respectively, the representative of the shipowner (Tevere Shipping), the president of the management company (Panship Management and Services Srl), the classification society (RINA) and Total SA all criminally liable for the offence of causing pollution. The Court of Appeal also confirmed the fines imposed by the Court of First Instance. The Court found, inter alia, that Total was imprudent in implementing its vessel vetting process and ordered Total to pay the original (criminal) fine imposed by the court of first instance, to the amount of $€_{375}, 000$. However, on the civil liability aspects of this case, the Court of Appeal reversed the finding of the Criminal Court of First Instance and decided that Total SA was 'de facto' the charterer of the Erika and could therefore benefit from the channelling provisions of Article III.4(c) of the 1992 CLC, since the imprudence committed in its vetting of the Erika could not be considered as having been committed with the intent to cause such damage, or recklessly and with knowledge that such damage would probably result. The Court of Appeal thus held that Total SA did not incur civil liability for the consequent oil spill. However, the appellate court also decided that the voluntary payments made by Total SA to the civil 
parties following the judgment of the Criminal Court of First Instance, were to be regarded as final payments which could not be recovered from the civil parties. 92 Significantly, Total did not contest this finding of the Court of Appeal.

Comparing the two case studies presented in this Part, the preemptive and comprehensive responses of $\mathrm{BP}$ and Total in the Deepwater Horizon and Erika incidents can be contrasted with the lack of immediate response by SPDC/Shell (Nigeria) in the Niger Delta region. It also speak volumes for the clear disparity in the respective corporate/host State relationships in Nigeria, as compared with the USA and France.

\section{Conclusions}

The present analysis concludes by highlighting legal developments heralding the accountability, responsibility, and even liability, for multinational oil companies that are implicated, involved or otherwise culpable in the breach of environmental standards: First, through the establishment by States of international civil liability schemes compelling individual legal persons involved in ultra-hazardous activities to contribute towards an established compensation fund. Relying on examples from the oil transport and nuclear power generation industries, it should be possible for States to expressly regulate by similar international agreements, liability for compensation for breaches of international law by private economic actors in many other fields of

\footnotetext{
${ }^{22}$ See: 'French oil company guilty but not responsible for ERIKA oil spill', The Maritime Executive Magazine website, April 1, 2010. Accessed from:

http://www.maritime-executive.com/article/french-oil-company-guilty-not-responsible-erika-oilspill
} 
transnational economic activity. This is coupled with recent examples in the US and France of international 'best practice' in corporate responsibility on the part of BP and Total, respectively, for the clean-up, remediation and compensation of environmental and other damages arising from oil spills, whether legally required to do so or not.

Finally, it remains to be seen whether the latest legal frontline that has been opened on this issue, namely, the cross-jurisdictional pursuit of the parent company, Royal Dutch Shell, through its subsidiary company, SPDC (Nigeria) in both Dutch and UK courts, will yield the requisite justice for the Niger Delta communities and its environment in the face of arguably decades of corporate misbehaviour in this region. Despite the withdrawal of the forum non conveniens doctrine in the Akpan and Bodo Community cases by The Hague district court and UK High Court, respectively, the continuing reluctance of both domestic courts (and international tribunals, such as the ITLOS) to ultimately extend international responsibility to private actors operating beyond their national jurisdictions is clear. In the same vein, the continuing absence of even suitable legal nomenclature denoting such responsibility for breaches of international norms by private actors is notable, in the sense that we still talk of 'State', responsibility for breaches of international law, as opposed to 'corporate' or 'individual' responsibility, apart from the imputation of individual criminal responsibility for war crimes. Within this context, enforcing responsibility and liability on the part of private economic actors operating transnationally across different national jurisdictions for their breaches of international norms must still be considered to be an aspiration rather than the reality. 